\title{
Determination of Free Fatty Acids: A Comparative Study of the Enzymatic Versus the Gas Chromatographic and the Colorimetric Method
}

\author{
By C. Mulder, \\ Department of Clinical Chemistry, Academic Hospital of the Free University, Amsterdam
}

\author{
J. A. Schouten and Corrie Popp-Snijders \\ Department of Internal Medicine, Academic Hospital of the Free University, Amsterdam
}

(Received March 18/July 11, 1983)

\begin{abstract}
Summary: We determined the concentration of free fatty acids in 51 plasma samples by three different methods: a gas-liquid chromatographic, a colorimetric and an enzymatic method. Values obtained by the three methods show a good correlation. The gas-liquid chromatographic method was used as the reference method. The results of the enzymatic method are about $5 \%$ too high and the colorimetric results have a bias of $+27 \%$. The coefficients of variation of the three assays are 4,7 and $5 \%$ respectively.
\end{abstract}

Storage of the samples at $-18^{\circ} \mathrm{C}$ gives no change in the total amount of free fatty acids, enzymatically determined.

Because of low costs (time, reagents and apparatus), combined with a sufficient accuracy and precision, the enzymatic method for the determination of total free fatty acids is the method of choice.

\section{Bestimmung der freien Fettsäuren:}

Vergleich voñ enzymatischer, gaschromatographischer und kolorimetrischer Methode

Zusammenfassung: Die Konzentration freier Fettsäuren wurde in 51 Plasmaproben mit drei verschiedenen Methoden bestimmt: einer gaschromatographischen, einer kolorimetrischen und einer enzymatischen Methode. Die mit den drei Methoden erhaltenen Werte zeigen eine gute Korrelation. Die gaschromatographische Methode wurde als Referenzmethode verwendet. Die Ergebnisse der enzymatischen Methode sind etwa 5\% zu hoch und die der kolorimetrischen Methode zeigen eine Abweichung von $+27 \%$. Die Variationskoeffizienten der drei Methooden sind 4, 7 und 5\%. Aufbewahrung der Proben bei $-18^{\circ} \mathrm{C}$ ergibt keine Änderungen der enzymatisch bestimmten gesamten freien Fettsäuren.

Wegen der geringen Kosten (Zeit, Reagenzien, Geräte) und zugleich ausreichender Richtigkeit und Genauigkeit ist die enzymatische Methode für die Bestimmung der gesamten freien Fettsäuren die Methode der Wahl.

\section{Introduction}

Free fatty acids can immediately supply energy, depending on the metabolic needs. Free fatty acids are readily absorbed, mainly by muscles and heart, as a preferential substrate for oxidation. Therefore determination of free fatty acids as a parameter of the metabolic state is very useful.
A number of methods have been proposed for the determination of free fatty acids in biological fluids. The first step of almost every assay is an extraction procedure. The extraction is followed by titrimetry $(1,2)$, colorimetry $(3-11)$, gas-liquid chromatography (GLC) $(12-14)$ or radiometry (15). 
In this hospital two different methods for the determination of free fatty acids are currently used: a colorimetric and a GLC method. The latter is used only if information about the composition of individual free fatty acids is required. Recently enzymatic methods have become available $(16,17)$ with the advantage that no extraction procedure is needed. To test the usefulness of such a method, we compared the results obtained using a commercial kit with those obtained by colorimetry and GLC. GLC was chosen as the reference method as this technique is sensitive and free of interference (18).

\section{Materials and Methods}

Plasma samples (EDTA) were collected from diabetic and nondiabetic out-patients. Blood was drawn after an overnight fast or postprandially. The blood samples were immediately centrifuged, and plasma promptly removed. For correlation studies the plasmas from 51 subjects were divided into three parts and stored under nitrogen at $-18^{\circ} \mathrm{C}$ for a maximum of 10 days.

For stability studies iwe used the control serum Seronorm Lipid batch 56 (Nyegaard) and 9 plasmas which were pipetted into test tubes and stored at $-18^{\circ} \mathrm{C}$ for a period from 0 to 29 days. They were then analysed by the enzymatic method.

\section{The gas-liquid chromatographic method}

To $0.5 \mathrm{ml}$ plasma is added $300 \mu \mathrm{l}$ internal standard (tricosanoic acid (purchased by Applied Science), $100 \mathrm{mg} / \mathrm{l}$ hexane), $1.5 \mathrm{ml}$ methanol, $5 \mathrm{ml}$ hexane and $1 \mathrm{ml} \mathrm{H}{ }_{3} \mathrm{PO}_{4}(1 \mathrm{mmol} / \mathrm{l})$. The tubes are shaken for $5 \mathrm{~min}$ and centrifuged. The hexane extract is evaporated under a stream of nitrogen and the lipid extract is transferred to pre-coated thin layer plates (silica gel.60F-254, Merck). The thin layer plates are developed in hexane: diethylether: acetic acid (volumes, $80+20+1$ ). Spots are visualized at $254 \mathrm{~nm}$ after spraying with a solution of $2 \mathrm{~g} / 1$ 2,7-dichlorofluorescein in ethanol. Free fatty acids are methylated by incubating the free fatty acid absorbed to the silica gel with $2 \mathrm{ml}$ of $\mathrm{H}_{2} \mathrm{SO}_{4}$ in methanol (40 $\mathrm{ml} / \mathrm{l})$ at $60^{\circ} \mathrm{C}$ during at least 2 hours. Methyl esters of the free fatty acids are extracted by adding $1 \mathrm{ml}$ of $\mathrm{H}_{2} \mathrm{O}$ and $3 \mathrm{ml}$ of hexane and shaking for 5 minutes. The hexane extract is dried with anhydrous $\mathrm{Na}_{2} \mathrm{SO}_{4}$ and subsequently evaporated by a stream of nitrogen at room temperature. The residue of free fatty acid methyl esters is dissolved in $40 \mu \mathrm{l}$ hexane, and $2 \mu \mathrm{l}$ is injected into a gas chromatograph (Hewlett Packard, model 402), equipped with a flame ionization detector. Gas chromatographic conditions are: column 10\% SP 2330 on chromosorb WAW 100:120 (Chrompack); carrier gas nitrogen $25 \mathrm{ml} / \mathrm{min}$; oven temperature $190^{\circ} \mathrm{C}$; injector and detector temperature $230^{\circ} \mathrm{C}$. Peak areas of each methyl ester are measured with an integrator (Hewlett Packard, model $3380 \mathrm{~A})$. The concentration of each fatty acid (mmol/l) is calculated as follows:

$$
c[\mathrm{mmol} / \mathrm{l}]=\frac{\text { peak area }}{\text { peak area }} \times \mathrm{F} \times c_{1 \mathrm{~S}}[\mathrm{mg} / \mathrm{l}] \times \frac{1}{M_{\mathrm{r}}}
$$

where $\mathrm{F}=$ detector response of an amount of the internal standard (IS) divided by the detector response of the same amount of fatty acid.

The total free fatty acid concentration is obtained by adding the individual molar concentration. The analysis is performed in duplicate.

\section{The colorimetric method}

We have used the method of Falholt et al. (6). To $50 \mu$ l sample is added $1 \mathrm{ml}$ phosphate buffer ( $\mathrm{pH} \mathrm{6.4)}$ and $6 \mathrm{ml}$ chloroform: heptane: methanol solution (volumes, $49+49+2$ ) in a test tube with polyethylene cap. This is shaken for $10 \mathrm{~min}$ and centrifuged $(4000$ $\left.\mathrm{min}^{-1} ; 10 \mathrm{~min}\right)$. The buffer is removed carefully by suction and 5 $\mathrm{ml}$ of the organic phase is shaken with $2 \mathrm{ml}$ of a solution containing $0.05 \mathrm{~mol} / \mathrm{Cu}\left(\mathrm{NO}_{3}\right)_{2}$ and $0.1 \mathrm{~mol} / \mathrm{l}$ triethanolamine; $\mathrm{pH} 8.1$ for $5 \mathrm{~min}$. After centrifugation ( $\left.4000 \mathrm{~min}^{-1} ; 5 \mathrm{~min}\right) 3 \mathrm{ml}$ of the upper phase is transferred to a test tube containing $0.5 \mathrm{ml}$ of a solution prepared from $10 \mathrm{ml}$ of $4 \mathrm{~g} / 1$ 1,5-diphenylcarbazide in ethanol and $0.1 \mathrm{ml}$ of $1 \mathrm{~mol} / 1$ triethanolamine and mixed carefully. Colorimetric determination is made after $15 \mathrm{~min}$ at $550 \mathrm{~nm}$ (Zeiss PMQ II). For the calculation a standard curve is prepared $(0.2,0.4,0.8$ and $1.0 \mathrm{mmol} / 1$ palmitic acid). These solutions are prepared by diluting a stock standard of $2.0 \mathrm{mmol} / \mathrm{l}$ palmitic acid in chloroform-heptane-methanol solution. To get acceptable results the analysis is performed in triplicate.

\section{The enzymatic method}

For the enzymatic method a commercial kit (NEFA-C test, WAKO LTD., Japan) is used. The analyses are performed according to the test procedure on the insert in the kit. The sample $(50 \mu \mathrm{l})$ is incubated with $1 \mathrm{ml}$ of a solution of acyl CoA synthetase (EC 6.2.1.3) for $10 \mathrm{~min}$ at $37^{\circ} \mathrm{C}$. Then $2 \mathrm{ml}$ reagent are added, which contains acyl CoA oxidase (no EC No. assigned). The formed hydrogen peroxide reacts with 4-aminoantipyrine and 3-methyl-Nethyl-( $\beta$-hydroxymethyl)aniline generating a red colour (fig. 1 ). The absorbance is measured at $546 \mathrm{~nm}$ (Vitatron). The test is performed in duplicate.

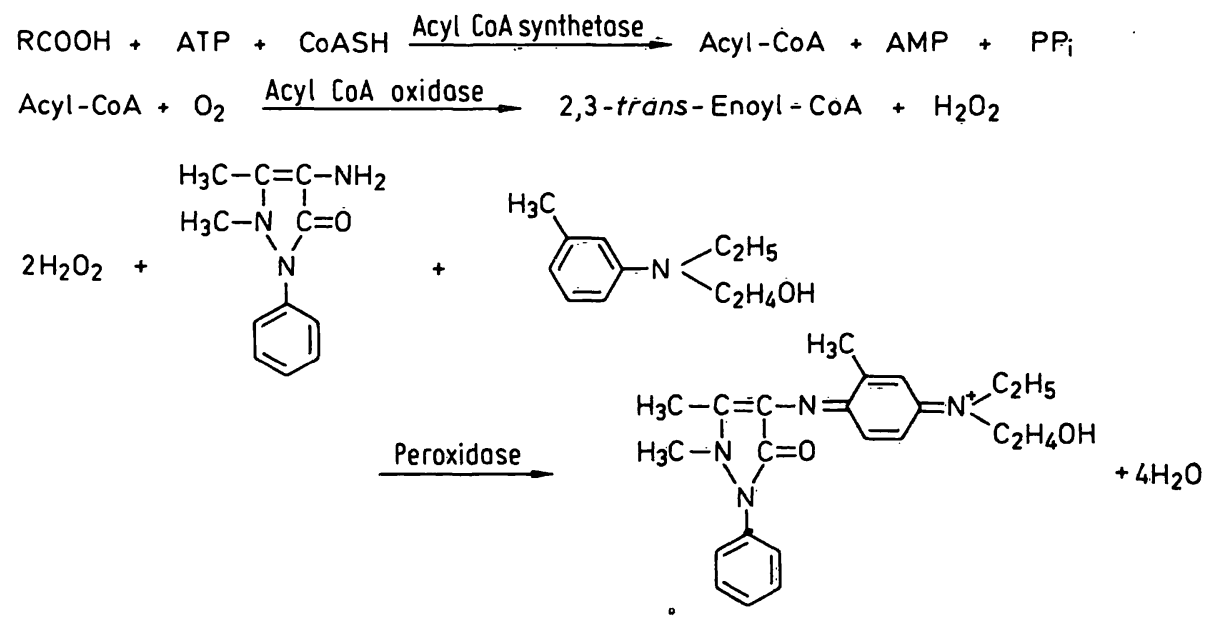

Fig. 1. Equations and formulae for the determination of free fatty acids by the enzymatic reaction 


\section{Results}

\section{Correlation studies}

The concentration of total free fatty acids was determined in the 51 plasma samples by the three different methods. The results of the correlation studies

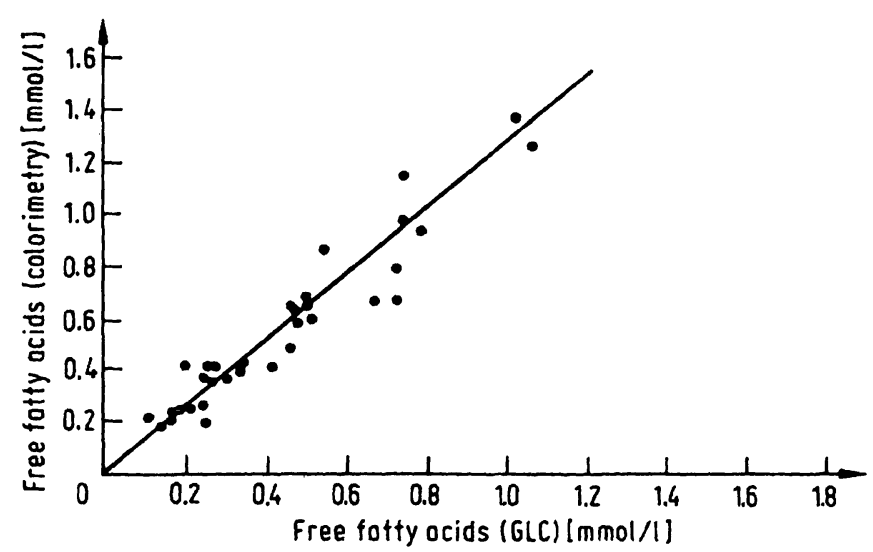

Fig. 2. The colorimetric $(y)$ versus the GLC $(x)$ method. Determination of free fatty acids: $y=0.003+1.268 x ; r$ $=0.972$

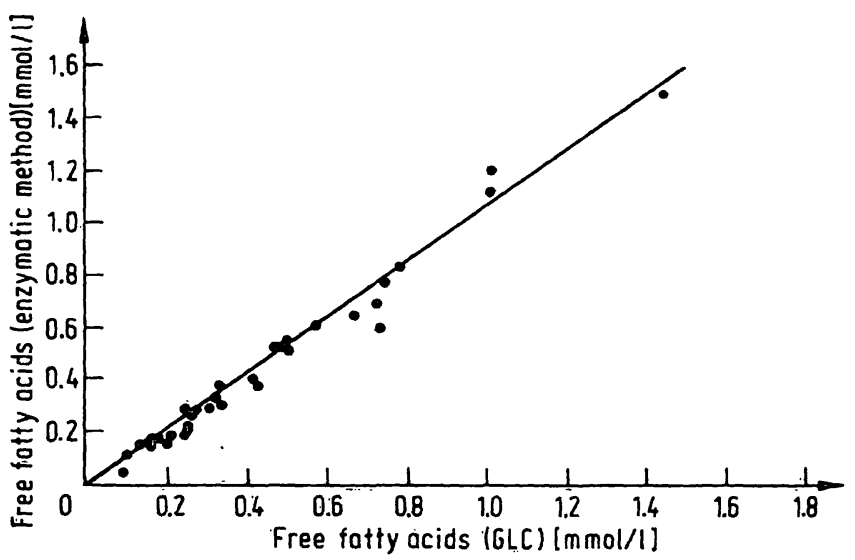

Fig. 3. The enzymatic (y) versus the GLC (x) method. Determination of free fatty acids: $y=-0.024+1.078 x ; r$ $=0.992$ are shown in figures 2,3 and 4 . When the colorimetric and the GLC method are compared (fig. 2), the intercept is negligible and the colorimetric results are $27 \%$ above the GLC results. Enzymatic values are slightly lower at low levels; at a level of $1.00 \mathrm{mmol} / \mathrm{l}$ they are about $5 \%$ higher than GLC values (fig. 3 ).

Similarly, at $1.00 \mathrm{mmol} / \mathrm{l}$ colorimetrically, the enzymatic results are $17 \%$ lower (fig. 4). The correlation between the three methods is very good, especially between the enzymatic method and GLC ( $r=$ 0.992).

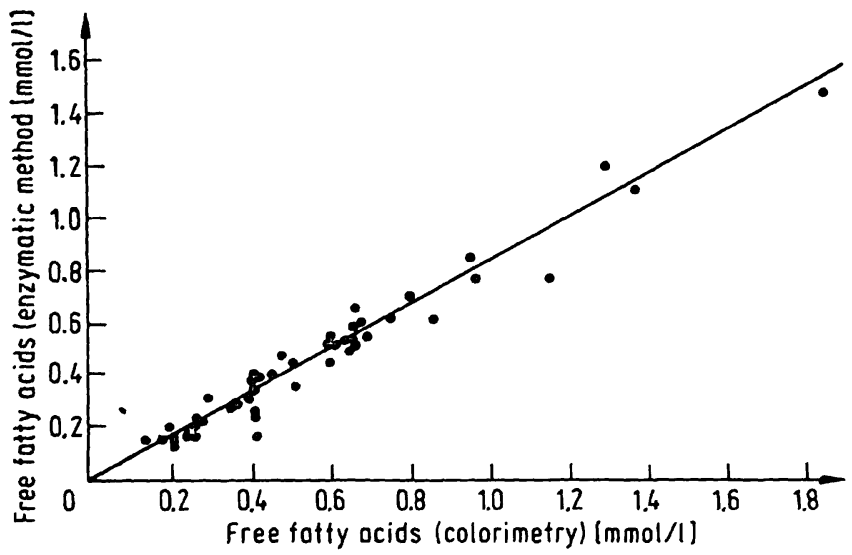

Fig. 4. The enzymatic $(y)$ versus the colorimetric $(x)$ method. $y=-0.021+0.847 x ; r=0.976$

Stability at $-18^{\circ} \mathrm{C}$

The stored control serum Seronorm Lipid (Nyegaard) and the 9 plasmas of outpatients were analysed at intervals by the enzymatic method. Table 1 shows that storage of samples at $-18^{\circ} \mathrm{C}$ for a period of four weeks gave no change in the total amount of free fatty acids enzymatically determined.

Tab. 1. The stability of the free fatty acid samples (mmol/l) at $-18^{\circ} \mathrm{C}$.

\begin{tabular}{llllllllllll}
\hline Day & $\begin{array}{l}\text { Seronorm } \\
\text { lipid }\end{array}$ & Plasma 1 & Plasma 2 & Plasma 3 & Plasma 4 & Plasma 5 & Plasma 6 & Plasma 7 & Plasma 8 & Plasma 9 \\
\hline 0 & 0.70 & 0.58 & 0.44 & 0.35 & 0.52 & 0.30 & 0.33 & 0.41 & 0.28 & 0.11 \\
2 & 0.71 & 0.58 & 0.46 & 0.35 & 0.53 & 0.30 & 0.32 & 0.42 & 0.29 & 0.13 \\
5 & 0.68 & 0.58 & 0.44 & 0.34 & 0.52 & 0.29 & 0.31 & 0.40 & 0.28 & 0.12 \\
7 & 0.69 & 0.58 & 0.44 & 0.35 & 0.52 & 0.29 & 0.32 & 0.41 & 0.29 & 0.12 \\
9 & 0.71 & 0.62 & 0.44 & 0.37 & 0.53 & 0.31 & 0.33 & 0.44 & 0.30 & 0.13 \\
12 & 0.69 & 0.57 & 0.44 & 0.36 & 0.52 & 0.29 & 0.32 & 0.41 & 0.29 & 0.12 \\
15 & 0.70 & 0.57 & 0.44 & 0.35 & 0.52 & 0.29 & 0.32 & 0.36 & 0.28 & 0.12 \\
19 & 0.71 & 0.64 & 0.48 & 0.37 & 0.53 & 0.35 & 0.38 & 0.43 & 0.34 & 0.16 \\
22 & 0.71 & 0.60 & 0.46 & 0.37 & 0.54 & 0.31 & 0.34 & 0.43 & 0.30 & 0.14 \\
29 & 0.69 & 0.59 & 0.44 & 0.36 & 0.51 & 0.30 & 0.33 & 0.41 & 0.29 & 0.12 \\
\hline Mean & 0.699 & 0.591 & 0.448 & 0.357 & 0.524 & 0.303 & 0.330 & 0.412 & 0.294 & 0.127 \\
S.D. & 0.011 & 0.023 & 0.014 & 0.011 & 0.009 & 0.018 & 0.020 & 0.022 & 0.018 & 0.015 \\
\hline
\end{tabular}




\section{Comparison of the precision of the three methods}

On 8 different days the control serum Seronorm Lipid (batch 56) was determined by the three methods. The mean values, standard deviations and coefficients of variation are shown in table 2 .

Tab. 2. Inter-assay variation $(N=8)$ of Seronorm Lipid, determined by the three methods.

\begin{tabular}{llll}
\hline & Enzymatic & Colorimetric & GLC \\
\cline { 2 - 4 } & 0.680 & 0.763 & 0.619 \\
Mean $(\mathrm{mmol} / \mathrm{l})$ & 0.035 & 0.054 & 0.025 \\
S.D. $(\mathrm{mmol} / \mathrm{l})$ & 5 & 7 & 4 \\
C.V. $(\%)$ & & & \\
\hline
\end{tabular}

\section{Discussion}

For this study we have taken GLC as the reference method. In this method the free fatty acids are separated from the phospholipids by thin layer chromatography. The colorimetric method does not involve such a separation procedure, resulting in interference by the phospholipids. Therefore free fatty acid values estimated by a colorimetric assay will be higher than those estimated by a GLC method. Demacker et al. (17) report that at normal concentrations of phospholipids $(3.5 \mathrm{mmol} / \mathrm{l})$ there is an overestimation of $0.12 \mathrm{mmol} / \mathrm{l}$ free fatty acids, whereas Chromy et al. (19) find this value to be $0.40 \mathrm{mmol} / \mathrm{l}$. Our results are just between those values. We find a bias of $+27 \%$ in our results obtained by the colorimetric assay. The enzymatic method shows values which are slightly above those of the reference method $(+5 \%)$. Previous recovery studies of this GLC method show a yield of $96 \%$. The agreement of the enzymatic method with the GLC method is very good, showing that this assay is sensitive as well as specific for free fatty acids. This specificity is due to the enzymatic conversion of the free fatty acids by means of acyl CoA synthetase and acyl CoA oxidase.

\section{References}

1. Dole, V. P. \& Meinertz, H. (1960) J. Biol. Chem. 235, 2595-2599.

2. Trout, D. L., Estes, E. H., Jr. \& Friedberg, S. J. (1960) J. Lipid Res. 1, 199-202.

3. Duncombe, W. G. (1964) Clin. Chim. Acta 9, 122-125.

4. Novak, M. (1965) J. Lipid Res. 6, 431-433.

5. Regouw, B. J. M., Cornelissen, P. J. H. C., Helder, R. A. P., Spijkers, J. B. F. \& Weeber, Y. M. M. (1971) Clin. Chim. Acta $31,187-195$.

6. Falholt, K., Lund, B. \& Falholt, W. (1973) Clin. Chim. Acta $46,105-111$.
The coefficient of variation of GLC agrees fairly well with that of the enzymatic method (4 and $5 \%$ respectively), while that of the colorimetric is considerably higher (7\%), notwithstanding the fact that GLC and enzymatic methods were performed in duplicate but colorimetry in triplicate.

The reference method is time consuming (about 10 determinations per day). The colorimetric method requires less time, but a skilled analyst cannot perform more than 20 assays a day. The enzymatic method is the least time consuming and simplest to handle.

The reagent for the enzymatic method is comparitively expensive, but the method can be very easily mechanized, which will reduce the quantity of reagent and ultimately the cost per analysis.

The apparatus required for the GLC method is rather expensive, while only a photometer is needed for the colorimetric and the enzymatic assays.

As appears from the results it is possible to store the plasma samples at $-18^{\circ} \mathrm{C}$ for the enzymatic determination of free fatty acids during a period of at least 4 weeks. Rogiers (20) found that the pattern of the individual fatty acids or the content of total free fatty acids in plassma changed after 48 hours, unless the sample was stored under nitrogen. In that case it was possible to store the plasma samples for 10 days at $-18^{\circ} \mathrm{C}$. All the determinations of Rogiers were performed with GLC.

Considering all the above aspects, the enzymatic method for the determination of total free fatty acids will be the method of choice in this hospital.

Note: Recently J. Miles et al. (21) have presented a microfluorimetric method for the determination of free fatty acids. The assay is a modification of the enzymatic method. The authors state that because of the sensitiviy of their assay, reagent, quantities and thus costs are significantly reduced compared with enzymatic spectrophotometric methods.

7. Solini, F. G. \& Sardina, L. C. (1973) Clin. Chem. 19, 419424.

8. Itaya, K. (1977) J. Lipid Res. 18, 663-665.

9. Boyer, D. E., Cridland, J. S. \& King, J. P. (1978) J. Lipid Res. 19, 274-280.

10. Bergman, S. R., Carison, E., Dannen, E. \& Sobel, B. E. (1980) Clin. Chim. Acta 104, 53-63.

11. Brunk, S. D. \& Swạnson, J. R. (1981) Clin.' Chem. 27, 924926.

12. McGee, J. \& Allen, K. G. (1974) J. Chromatogr. 100, 3542. 
13. Wirth, A., Eckhard, J. \& Weicker, H. (1976) Clin. Chim. Acta $71,47-54$.

14. Heckers, H., Dittmar, K., Melcher, F. W. \& Kalinowski, H. O. (1977) J. Chromatogr. 135, 93-107.

15. Ho, R. J., (1970) Anal. Biochem. 36, 105-113.

16. Shimizu, S., Tani, Y., Yamada, H., Tabata, M. \& Murachi, T. (1980) Anal. Biochem. 107, 193-198.

17. Demacker, P. N. M., Hijmans, A. G. M. \& Jansen, A. P. (1982) Clin. Chem. 28, 765-768.
18. Kitchell, B. B., Lazar, J. D., Whorton, A. R., Donegan, C. \& Molan, J. A. (1981) Clin. Chem. 27, 356-357.

19. Chromy, V., Gergel, J., Voznicek, J., Krombholzova, L. \& Musil, J. (1977) Clin. Chim. Acta 80, 327-332.

20. Rogiers, V. (1978) Clin. Chim. Acta 84, 49-54.

21. Miles, J., Glasscock, R., Aikens, J., Gerich, J. \& Haymond, M. (1983) J. Lipid Res. 24, 96-99

\section{Drs. C. Mulder}

Academic Hospital of the Free University

Dept. of Clinical Chemistry

Postbus 7057

NL-1007 MB Amstcrdam 
, 